\title{
BEYOND THE INDUSTRIAL ENGINEERING FRONTIER: A FEW STEPS IN HISTORY AND A GIANT LEAP INTO THE FUTURE
}

\author{
M. Mangaroo-Pillay ${ }^{1 *} \&$ M. Roopa ${ }^{1}$
}

\section{ARTICLE INFO}

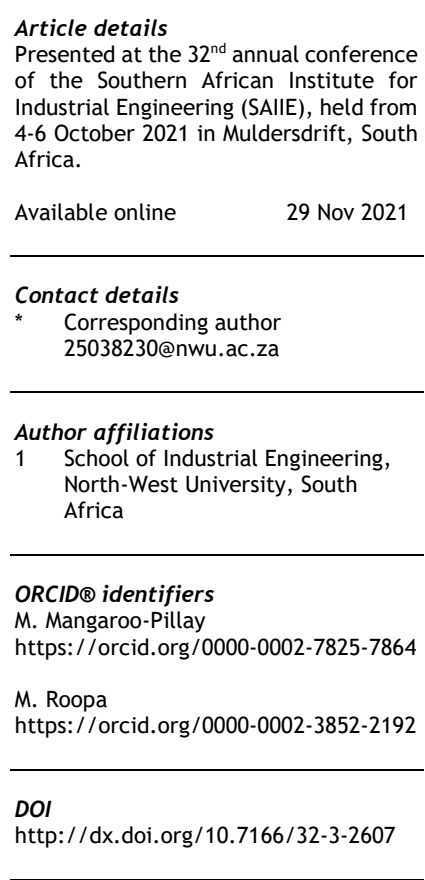

ABSTRACT

Industrial engineering is a discipline that has grown parallel to that of the industrial revolutions. However, what are the next steps for the industrial engineer of the future? In the wake of constant change and technological developments, there is a call for industrial engineers to reflect on the past and to plan for what may await. Amidst a global pandemic, the need for reflection and planning may be of greater importance now more than ever before. This paper serves as a recollection of the key steps taken to develop industrial engineering in history and explores what the future may hold for the field. The ideas of the discipline's pioneers are presented in the study, and the visions of up-and-coming key players are consolidated in order to predict the future of industrial engineering.

\section{OPSOMMING}

Bedryfsingenieurswese het as vakgebied saam met die industrie se revolusies gegroei en ontwikkel. Wat is die volgende stappe vir die bedryfsingenieur van die toekoms? Dit is belangrik dat bedryfsingenieurs, te midde van die volgehoue ontwikkeling van tegnologie, leer uit die verlede en beplan vir dit wat voorlê. Dit is selfs belangriker tydens 'n globale pandemie. Hierdie artikel oorweeg die sleutel stappe wat geneem is om bedryfsingenieurswese te vestig en ondersoek wat die toekoms vir die vakgebied mag inhou. Die idees van die dissipline se baanbrekers word saamgevoeg in 'n poging om die toekoms van bedryfsingenieurswese te voorspel.

\section{INTRODUCTION}

Instinctively, one of the very first objectives of human beings is to achieve motion or be able to move. Our initial steps are uncoordinated, with little confidence, and need supervision. Although we may stumble and fall, eventually, with the right vision and confidence, we reflect and learn how to walk. In a similar vein, the emergence, growth, and development of industrial engineering has overcome many hurdles, and grown in confidence and popularity over the years. The field of industrial engineering has learnt to crawl, take its first steps, walk and run - and may even compete at the Olympics in time to come.

Industrial Engineering is a complex, multidisciplinary field that has sparked innovation, creative problemsolving, and advances in the world around us. As early as 1911, Going [1] associated the field of industrial engineering with the fulfilment of human tasks in manufacturing, construction, transportation, and commercial enterprises. Furthermore, it was explained that industrial engineering merges older sciences with aspects of economics and human elements. In 1985, the Institute of Industrial Engineers (IIE) defined it in these terms $[2,3]$ :

"Industrial Engineering is concerned with the design, improvement and installation of integrated systems of people, material, information, equipment and energy. It draws upon specialized knowledge and skill in the mathematical, physical and social sciences together with the principles and methods of engineering analysis and design to specify, predict and evaluate the results to be obtained from such systems." 
Over time, that definition has exploded into different branches in industrial engineering, giving rise to multiple niches of application [2, 4]. This discipline has grown parallel to the industrial revolutions. But what are the next steps for the industrial engineer of the future? In the wake of constant change and technological developments, there is a call for industrial engineers to reflect on the past and to plan for what may await.

This paper aims to present thoughts, ideas, and discussions on the development and future of industrial engineering.

\section{TIMELINE OF INDUSTRIAL ENGINEERING}

In order to appreciate being able to run, industrial engineers need to recognise and reflect on the stages when we crawled, took our first steps, and learnt to walk. These moments in history are captured in a timeline that highlights our achievements. These achievements gave rise to advanced technologies with high levels of interaction and dependency that can be paralleled to the industrial revolutions. Figure 1 is testament to the strides owed to each revolution.

From Figure 1, it is evident that the growth of focus areas is increasing exponentially with time and with each new industrial revolution. During the first and second industrial revolutions, the development of scientific management could be seen in the establishment of focus areas such as time studies, standardisation, mass production, motion study, queueing theory, management, inventory planning, and statistical quality control.

During the second and third industrial revolutions, the expansion of industrial engineering and operations research was indicative of the formation of focus areas such as engineering economics, material handling, productivity, human factors, networking techniques, decision theory, inventory theory, systems engineering, simulation, automation, (MRP) and information systems.

In current times, during the late third and early fourth industrial revolution, the advances in industrial and systems engineering can be observed. While this era is still under way, artificial intelligence, computerintegrated manufacturing, lean, robots, systems design, computer networks, control theory, total systems design, social systems, cybernetics, and behavioural theory focus areas have been recognised.

\section{ANCIENT HISTORY}

It could be argued that the first strides that resembled those of an industrial engineer were taken prior to the first industrial revolution, as ancient societies began nurturing and adapting the skills, knowledge, and thinking that define us today.

Considering the early humans who lived in caves, not only did they trudge through and persevere against harsh conditions, but many of their daily lives also relied on active decision-making. This included strategies of hunting collectively, using limited resources efficiently, and dedicating roles and responsibilities, to name a few [6]. Furthermore, we had now mastered fire, tool-making, communicating through cave paintings, and making clothes [7].

Agrarian societies began taking larger strides with more weight, and lasting impressions that we marvel at today. First and foremost, our means of hunting had significantly improved. Animals were domesticated as we began settling in areas that would sustain livelihoods. Here was where we learnt that continuous migration could be substituted with societies that congregated, shared, and depended on one another. The everyday routes and familiar footprints now replaced new territories that would have been explored. In this way, the need to adapt sustainable practices became more prevalent [6]. Arguably, these were the fundamental characteristics that laid the foundations of a modern industrial engineer, such as the idea of optimising what you had in order to have bigger production yields and larger 'profits' (gains).

Although these traits were representative of our problem-solving nature, our strides as industrial engineers were first discovered and documented in the 1900s. 


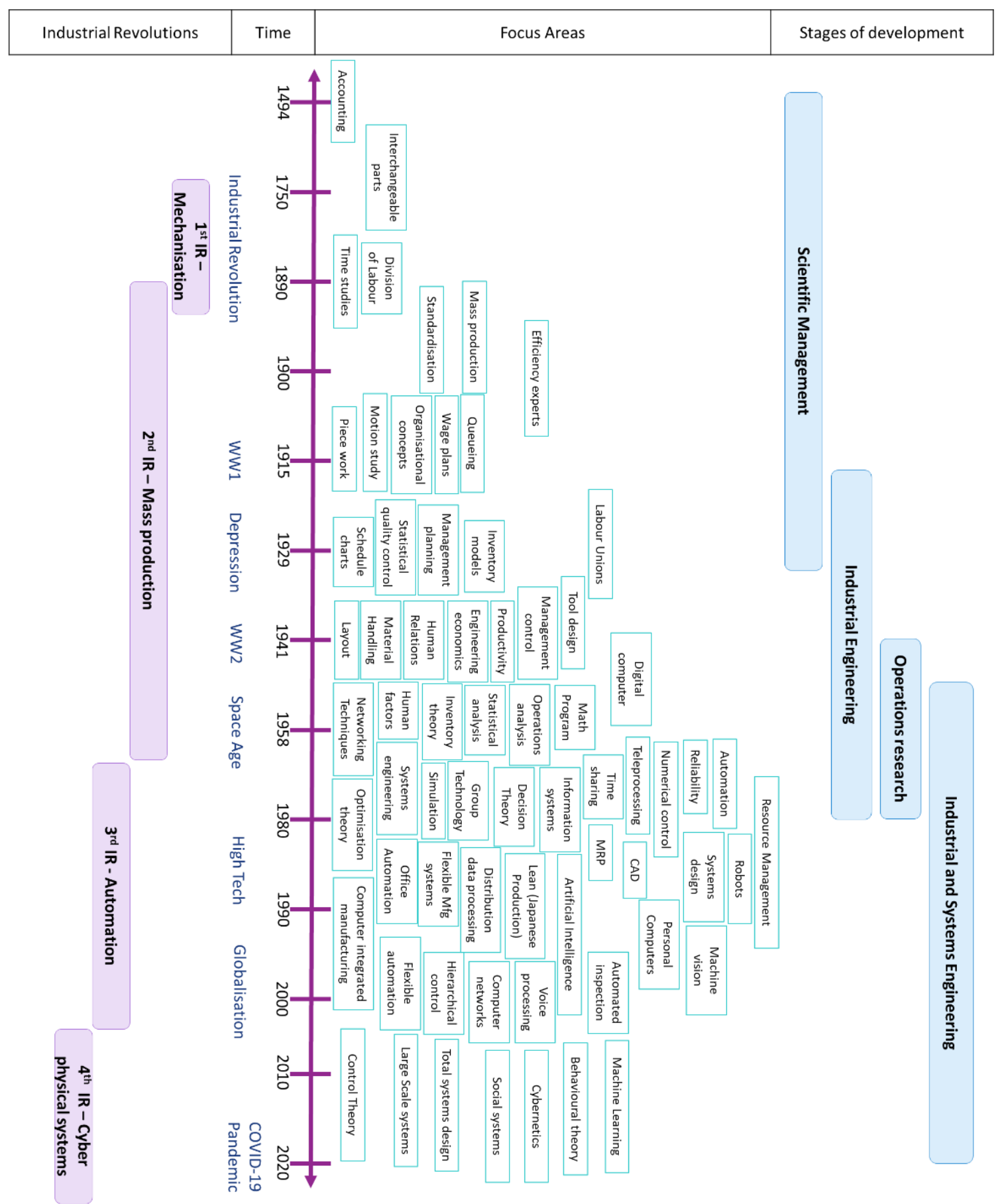

Figure 1: Timeline of the development of industrial engineering (adapted from Turner et al. [5])

\section{MODERN HISTORY}

The modern era (from the 1400s) welcomed further specialisation in skills and trades. In Figure 1, the special skillset of industrial engineers starts with accounting systems in 1494. In this year, the mathematician Luca Pacioli introduced double-entry bookkeeping and published the first printed book on geometry $[5,7]$. While this was a significant time in the past, its teachings are prevalent in current accounting and engineering economics systems. Not long after, in the 1500 s, Leonardo da Vinci designed 
machines and mechanisms such as lathes and screw thread cutting machines, which were unprecedented at the time. Sperotto [7] argues that Da Vinci may have been one of the first engineers to explore human motor systems. Da Vinci's human explorations may have unconsciously planted the seed of ergonomics, which is crucial to modern industrial engineering.

In 1784 the first industrial revolution was underway, leading to the birth of mechanisation [8, 5]. Eli Whitney introduced interchangeable parts for machinery during this revolution [9]. Whitney's contributions increased efficiency in the manufacturing industry by enabling unskilled workers to produce larger volumes for lower costs and with shorter changeover times.

Henry Ford may be one of the best-known industrial engineers, cementing his place in the history books by being the first to install moving assembly lines for mass production [10]. These assembly lines continue to play a vital role in modern production systems and facilities design.

Frederick Taylor is regarded as the father of scientific management, with one of his greatest contribution being time and motion studies [11, 12]. To a large extent, our fixation on time and efficiency, along with its importance, is part of our primal instinct as industrial engineers. Currently, time is of the essence in the fast-paced world of engineering.

Lillian Gilbreth broke ground in industrial management techniques, while her husband Frank Gilbreth specialised in technical work efficiencies [13]. They contributed significantly to standardisation, management systems, division of labour, and efficiencies. These practices are still used in most industrial engineering systems. Their contribution to operating rooms was the first application of industrial engineering in the healthcare sector.

In the wake of the second industrial revolution, Agner Krarup Erlang established the field of telephone network analysis while building the foundations of queuing theory [14]. The application of queuing theory is still found in the traffic analysis, supply chain, and service environments.

William Edwards Deming played a huge role in quality control systems and total quality management (TQM) while advocating for the PDCA cycle and Lean in the United States of America [15]. His teachings in TQM still play a vital role in the success of many firms today.

In the 1940s, George Bernard Dantzig devised the Simplex method, an algorithm used in decision support systems [16]. This algorithm has inspired new heuristic and non-heuristic algorithms that continue to develop. His work contributed significantly to optimisation theory, which joined the realm of industrial engineering in the 1980s. With the rise in computing technology and globalisation, this algorithm will remain vital to industrial engineering.

JW Forrester, the father of systems dynamics, not only pioneered this field in the 1950s, but is also credited with creating the first computer animation [17]. For industrial engineers, his impact on computer systems and systems dynamics has strengthened our understanding of the world around us.

By the 1980s, Alan B. Pritsker had founded computer simulations in the field of operations research [18]. The advantages of numeric solutions have empowered industries and companies with the necessary decision support for complex, nonlinear systems over predetermined time periods.

Although MRP systems were invented in 1964 by Joseph Orlicky, they were only adopted in the field of industrial engineering in the 1980s [19]. The focus on resource consumption for the purposes of production scheduling sustains today's high demand for products.

Taiichi Ohno, the father of the Toyota production system (TPS), is credited with the creation of Lean and other management tools in the mid-1900s [20]. In the 1980s his teachings and work grew in popularity, with Lean being adopted worldwide. Shigeo Shingo is credited with inventing TPS, and is most famously known for the introduction of Poka-yoke and single minute exchange of dies (SMED). These concepts are at the heart of many production lines today.

In the $21^{\text {st }}$ century, the successes of industrial engineering continued to produce new value, profit, and success in a multitude of industries. Some of the key players of modern industrial engineering are still 
taking their first steps in innovation. While they are still walking their personal journeys, their footsteps are worth commending, as their paths are inspirational to many.

A noteworthy footpath is that trod by Alphonse Chapanis, the forefather of ergonomics and human factor engineering [21]. This field is advanced by the continuous development of new technology and equipment. In many ways, the principles of human-centred processes rely on the weighty steps of Alphonse Chapanis.

Eliyahu M. Goldratt is most famously known for his work on the Theory of constraints [22]. This is considered to be one of the most recent theories to emerge in the sphere of continuous improvement.

Another significant engineer is Tom Gilb, the founder of the Agile programming methodology and Planguage [23]. As we are now in the Fourth Industrial Revolution, his contributions continue to sustain software systems development and project management.

Several industrial engineers have spearheaded organisation in the roles of CEOs, managers and leaders, guiding their companies to success via industrial engineering tools and techniques. Dick Kovacevich is a well-established CEO of Wells Fargo, a US bank [24]. Fargo has showcased the value of IE techniques in the banking world, with respect to having a sound understanding of effective customer relationship management.

AT\&T is the world's largest telecommunications organisation, with Edward Whitacre as its CEO [25]. Whitacre has been credited with using his great understanding of the business world to lead the organisation through a series of strategic acquisitions and expansions. Before his time at AT\&T he was the chairman and CEO of General Motors. His contributions at both organisations are testament to the diverse nature and value of industrial engineering applications.

An unorthodox use of an industrial engineering qualification is that by Joe Giradi, the manager of the Philadelphia Phillies baseball team and ex-manager of the Yankees [26]. He highlighted the valuable use of data and statistics for active decision-making during baseball games.

Accenture, an international consulting and data processing company, had an industrial engineer as their former CEO, John Forehand [27]. Forehand contributed significantly to rebranding the organisation by reembodying its value preposition and accentuating the company's image. This ties in well with modern views on business engineering and design.

The late Lee lacocca may be best known for his development of the Mustang at Ford. However, he was also renowned for being the former CEO of Chrysler [28]. His fundamental contributions aided Chrysler in overcoming bankruptcy, and he embodied transformational leadership. The resilience and financial mindset honour the skillset that an industrial engineer must have to remain relevant, dynamic and valuable today.

As industrial engineers, logistics and supply chain management are fundamental pillars of our day-to-day work. Michael Eskew, former United Parcel Service (UPS) CEO, used his skills to diversify operations and services at the organisation with data-driven logistics [29]. Similar contributions in the field were made by Mike Duke, the former CEO of Walmart, having aided in the design and implementation of innovative technologies [30]. Parcel services and e-commerce have become essential functions in the COVID-19 era, and will most likely expand in the years to come.

NASA astronaut Rex Joseph Walheim took steps for industrial engineers in space. Walheim was part of the first team to use a robotic arm to manoeuvre space walkers around the international space station [31]. Floating amongst the stars, he performed scientific space walks to aid the Columbus laboratory. He helped to create a better understanding of fuel behaviour, pump design and failure mechanisms that improved space safety. His contribution emphasises the importance of processes and systems that are vital to industrial engineering.

The Apple Inc. CEO, Tim Cook, is a notable industrial engineer who has led sales, services, and support as well as supply chain practices in various parts of the world. The power of inventory management and waste elimination elevated his reputation - and the performance of the organisation [32]. Competing in the same space, Yun Jong Yong (Samsung CEO) has also made immense contributions to his organisation. Rallying his industrial engineering skills, he pushed Samsung to the top of international rankings by boosting productivity and reducing production times [33]. Once more, the harmonious combination of industrial engineering and business strategy demonstrates how larger strides can be taken. 
Kuntoro Mangkusubroto is most renowned for his contributions towards achieving sustainability goals, with massive contributions towards facilitating green economy transitions, through the United Nations [34]. However, he is also the former head of the presidential unit of development, supervision and control in Indonesia. His work has laid the foreground for many other initiatives or programmes. With the rise in global pollution, sustainability considerations and policy development will only have ever-growing needs. With their holistic understanding of the dynamic world, industrial engineers are well-equipped to address these needs.

With the increase in demand for technologies, investors such as Gideon Yu are highlighting the value of industrial engineering and of our role in technology adaption and advancement [35]. He is also an adviser on high technology implementation, recognising the challenges and intricacies that come into play. Another recognised investor is Douglas Leone, who has specialised in internet, software and communication investments [36]. Their understanding of technology, economics and business positions industrial engineers to make optimal investment decisions.

The efforts and successes of industrial engineers are implemented through a formalised profession with a sense of specialisation. South Africa is no exception to this. While the development and contributions of local engineers are unprecedented, the profession is still in the youth of its development. It is believed that, in the near future, South African industrial engineers will have a greater footprint in the international domain. Industrial engineers in South Africa have various areas of specialisation within the field. According to the Organising Framework for Occupations (OFO), industrial engineers have various areas of specialisation across different industries, such as [37]:

- $\quad$ Agri-produce process

- $\quad$ Automation and control

- Clinical

- $\quad$ Enterprise resource management

- Fabrication

- Industrial efficiency

- Industrial machinery

- Manufacturing logistics

- Manufacturing technology

- Operations research

- Production plant

- $\quad$ Process design

- Processes

- $\quad$ Production

- Quality management

- Robotics and production automation

- Safety

- Supply chain management

- Value engineering

While these areas of specialisation warrant their own identities, their common purpose is to employ creative problem-solving to innovate, integrate and improve processes and systems.

\section{FUTURE OF INDUSTRIAL ENGINEERING}

The influx of Industry 4.0 technologies is revolutionising the world of operations, business and services. Four disruptive trends - (1) big data, (2) advanced analytics, (3) human-machine interfaces, and (4) digitalto-physical transfer - have the largest impact on numerous sectors [38]. As masters of integration, who else is better suited to instil these changes with the utmost care and consideration for people, processes and technology than industrial engineers? Society 5.0 is a Japanese transformational plan that aims to integrate people with the cyberspace that Industry 4.0 technologies have created in order to solve social problems and ensure economic development [39]. For similar countries, these transitions will need the human-technology understanding that industrial engineers are familiar with.

Moreover, in the wake of the global Covid-19 pandemic, Murata [40] suggests that industrial engineers are ideally equipped to bridge the gaps that have been created. It is advised that industrial engineers use the opportunities provided by Industry 4.0 to create opportunities for physical human interaction. 
The Covid-19 pandemic has placed a sudden halt in all of our journeys. This obstacle has forced us to look toward new horizons, retrace our steps or even make sudden leaps into unknown territory. Much like the pioneers of industrial engineering, we require a new outlook, perspective and way of advancing and continuing our run.

Industrial engineers, like any other profession, offer specialised skills and knowledge that can remedy the negative effects of Covid-19. One of the first areas of improvement is with regard to vaccination rollout and administration. Simulation studies can be used to understand the logistics and behaviour of mass drive through vaccinations, as demonstrated by Asgary et al. [41]. On the other hand, simulation software can show us how the virus spreads and its behaviour in different conditions [42]. The management of the healthcare industry, medical resources and medical personnel can be optimised using systems thinking. By using machine learning, the resource allocation, healthcare systems and policies can be investigated for decision support purposes [43]. As we continue to address the adversities that Covid-19 has brought, the problem-solving abilities of industrial engineering will aid us in recovering and re-establishing society now and for the post-Covid-19 era.

A study by Dastkhan and Owlia [44] explored research trends in the field of industrial engineering. One of their findings were domains offering a high potential for interaction with other disciplines. In order from the highest potential to the lowest, these were operations research, intelligent systems, production management, method engineering, quality management, advanced production systems, supply chain management, information technology, and project management. Schutte et al. [45] supported these findings with independent studies conducted in local industrial engineering publications at SAJIE, obtaining similar results.

The ever-changing role of industrial engineers dictate the tempo of change in organisations. For developing countries, this could not be truer [46]. The issues of crime, poverty, unemployment, and limited skills can be addressed through innovation and through balancing socio-economic factors. It is argued that future industrial engineers should focus less on profits and more on identifying products, services, education and training [46]. While this is a drastic tangent to the roots of industrial engineering, the industrial engineer of the future will need to create new opportunities for growth and development. It is also believed that the crux of the profession will remain grounded in manufacturing while venturing into new industries [46].

Balasubramanian [47] suggests that new arenas of industrial engineering in the future could include:

- $\quad$ Production control and distribution management

- Manufacturing management and processes

- Man-machine interface design

- $\quad$ Operations research and systems engineering

The industrial engineers of the future will find themselves "collaborating with IT to lead the application in manufacturing, distribution, logistics, supply chain and service facility design and quality assurance" [47]. It is suggested that industrial engineers of the future must be able to integrate human psychology and the physiological sciences in order to optimise interface design [47].

\section{CONCLUSION}

This discussion paper presents the range of motion, the journeys taken, and the steps we eagerly anticipate for the future of industrial engineering. The future explorations of industrial engineers may be undertaken with varying strides at independent speeds and in different directions. However, the eindustrial engineer of the future will be equipped to handle problems that we might not be able to imagine now. While the original definition of industrial engineering dates back to the $1900 \mathrm{~s}$, it is so all-encompassing that it will continue to remain inclusive of the wide range of roles that the future industrial engineer might have.

When walking, human mechanics are designed such that, at any point, one foot must remain on the ground. Similarly, for large corporations and engineers, this resembles our constant interaction with communication and knowledge in order to remain upright. For small and large companies, they stand upright with a certain stature and range of motion, those that are smaller might need to walk faster to keep up with the larger companies - but they are at least more flexible and dynamic in how they respond to changing environments. 
The precise shape of industrial engineering in the future might be unknown; but it is definitely big and bright. Based on the journey that industrial engineers have taken, it is evident that their roles in integration will continue to serve as part of their core values. As the world becomes more technologically advanced, industrial engineers must be at the intersection between people and technology. It is obvious that, as engineers, industrial engineers will develop more advanced technological skills as technology advances. However, it is crucial that they work to strengthen their knowledge of systems engineering, environmental factors, and human factor engineering, paralleled to their development of technical engineering skills. This will facilitate the engineering of processes and systems for products and ideas that have not yet been invented.

Given that industrial engineers have been recognised for their contribution to industries in the form of tangible improvements, their problem-solving abilities will transcend to intangible improvements and innovations (e.g., work models, ways of thinking, system consciousness and more). The industrial engineer will innovate, inspire, and share new ways of thinking that will start to re-define our approach to policymaking and legislation, and to political, social, environmental, educational, inequality, transformational, sustainability, and health issues. They will start solving these macro-scale problems and securing future prosperity.

This journey through time has allowed us to appreciate the very first steps in industrial engineering's history, while preparing us to take a giant leap into the future and beyond.

\section{REFERENCES}

[1] C. Going, Principles of industrial engineering, McGraw-Hill Book Company, 1911.

[2] G. Salvendy, Handbook of industrial engineering: Technology and operations management, John Wiley \& Sons, 2001.

[3] E. Elsayed, "Industrial engineering education: A prospective," European Journal of Engineering Education, vol. 4, no. 24, pp. 415-421, 1999.

[4] P. Kruger, "Industrial engineering; Rooting for roots, hankering for heroes," Southern African Journal of Industrial Engineering, vol. 2, no. 14, pp. 137-147, 2003.

[5] W. Turner, K. Case and J. Nazemtz, Introduction to industrial and systems engineering, Pearson College Division, 1993.

[6] Y. Harari, Sapiens: A brief history of humankind, Random House, 2014.

[7] F. Sperotto, In the footsteps of Homo Industrialis: A chronology of industry and industrial engineering, Picsie Press, 1994.

[8] W. Rennen and P. Martens, "The globalisation timeline," Integrated Assessment, vol. 3, no. 4, pp. 137-144, 2003.

[9] R. Woodbury, "The legend of Eli Whitney and interchangeable parts," Technology and Culture, vol. 1, no. 3, pp. 235-253, 1960.

[10] J. Wilson, "Henry Ford vs. assembly line balancing," International Journal of Production Research, vol. 52, no. 3, pp. 757-765, 2014.

[11] D.P.H.L. Gantt and F. Taylor, "The pioneers of scientific management," AACE International Transactions, pp. 1$15,2007$.

[12] F. Sperotto, "The development of the industrial engineering profession in South Africa," South African Journal of Industrial Engineering, vol. 2, no. 26, pp. 1-9, 2015.

[13] F.T. Mousa and D.J. Lemak, "The Gilbreths' quality systems stands the test of time," Journal of Management History,vol.15, no.2, 2009.

[14] Z. Bojkovic, M. Bakmaz and B. Bakmaz, "Electrical engineering wall of fame," Proceedings of the IEEE, vol. 1, no. 98, pp. 123-127, 2009.

[15] R. Moen and C. Norman, "Evolution of the PDCA" 2006.

[16] G. Dantzig, "Origins of the simplex method," A history of scientific computing, Association for computing machinery, pp. 141-151, 1990.

[17] J. Forrester, "System dynamics-the next fifty years," System Dynamics Review: The Journal of the System Dynamics Society, vols. 2-3, no. 23, pp. 359-370, 2007.

A. Pritsker, "Compilation of definitions of simulation," Simulation, vol. 2, no. 33, pp. 61-63, 1979.

B. Ptak and C. Smith, Orlicky's material requirements planning, McGraw-Hill Education, 2011.

[18] J. Liker, Toyota Way: 14 management principles from the world's greatest manufacturer, McGraw-Hill, 2004.

[19] C.T. Morgan, J.S. Cook, A.E. Chapanis and M.W. Lund, Human engineering guide to equipment design, McGrawHill, 1963.

[20] E.M. Goldratt and J. Cox, The goal: A process of ongoing improvement, Routledge, 2016.

[21] T. Gilb and S. Finzi, Principles of software engineering management (Vol 11), Addison-Wesley, 1988.

[22] D. Kovacevich, “'Boring' banking to dynamic financial services," ABA Banking Journal, vol. 11, no. 100, p. 68, 2008.

[23] Reference for Business, "Edward Whitacre," Advameg, 2021. [Online]. Available:

https://www.referenceforbusiness.com/biography/S-Z/Whitacre-Edward-E-Jr-1941.html. 
[24] American Society of Mechanical Engineers (ASME), “Joe Girardi: From engineer to Yankees manager,” 23 May 2011. [Online]. Available: https://www.asme.org/topics-resources/content/joe-girardi-from-engineer-to-yankeesmanager.

[25] J.G. Kaikati and A.M Kaikati, “A rose by any other name: Rebranding campaigns that work, Journal of Business Strategy,vol 24, no.6, 2003.

[26] M. Seeger, "CEO performances Lee lacocca and the case of Chrysler," Southern Speech Communication Journal, vol. 1 , no. 52, pp. 52-68, 1986.

[27] W. Kenton, “Michael L. Eskew,” Investopedia, 23 February 2021. [Online]. Available: https: / /www.investopedia.com/terms/m/michae-l-eskew.asp.

[28] Georgia Tech, "Mike Duke elected to the National Academy of Engineers," [Online]. Available: https://www.isye.gatech.edu/news/mike-duke-elected-national-academy-engineers.

[29] NASA, "Rex J. Walheim (Colonel, U.S. Air Force, Ret.) NASA Astronaut," [Online]. Available: https: / /www.nasa.gov/astronauts/biographies/rex-j-walheim/biography.

[30] M. Richtel, “Tim Cook: Making Apple his own," New York Times, Technology, 2014.

[31] Reference for Business, “Yun Jong-yong," Advameg Inc., [Online]. Available: https: //www.referenceforbusiness.com/biography/S-Z/Yun-Jong-yong-1944.html.

[32] United Nations, “Indonesia's green economy corridor initiative," United Nations, 2012. [Online]. Available: https: / / sustainabledevelopment.un.org/index.php?page=view\&type=99\&nr=280\&menu=1449.

[33] Society For Science, “Gideon Yu,” [Online]. Available: https://www.societyforscience.org/people/gideon-yu/.

[34] PitchBook, “Douglas Leone," PitchBook, 2021. [Online]. Available: https://pitchbook.com/profiles/investor/110293-30.

[35] Engineering Council of South Africa, ECSA - Discipline-specific training guidelines for professional engineers in Industrial Engineering, Engineering Council of South Africa (ECSA), 2013.

[36] S.M. Sackey and A. Bester, "Industrial engineering curriculum in Industry 4.0 in a South African context," South African Journal of Industrial Engineering, vol. 4, no. 27, pp. 101-114, 2016.

[37] M. Fukuyama, "Society 5.0: Aiming for a new human-centered society," Japan Spotlight, Jul/Aug , no. 27, pp. 47$50,2018$.

[38] K. Murata, "On the role of industrial engineering in the COVID-19 era," Proceedings of International Conference on Engineering and Information Technology for Sustainable Industry, pp. 1-5, 2020.

A. Asgary, M.M. Najafabadi, R. Karsseboom and J. Wu, "A drive-through simulation tool for mass vaccination during COVID-19 pandemic," Healthcare, vol 8 , no.4, 2020.

[39] M. Alhammadi and W. Khalil, "Simulation of coronavirus spread: Concerns and facts," Proceedings of the 5th NA International Conference on Industrial Engineering and Operations Management, pp. 1050-1062, 2020.

[40] M. Buckheit, “Industrial engineering department pivots to address COVID-19," [Online]. Available: https: //news.psu.edu/story/621285/2020/05/26/research/industrial-engineering-department-pivots-addresscovid-19.

[41] H. Dastkhan and M.S. Owlia, "Study of trends and perspectives of industrial engineering research," South African Journal of Industrial Engineering, vol 20, no.1, pp. 1-12, 2009.

[42] C.S.L. Schutte, D. Kennon and W. Bam, "The status and challenges of industrial engineering in South Africa," South African Journal of Industrial Engineering, vol. 1, no. 27, pp. 1-19, 2016.

[43] G. Lister and K. Donaldson, "New roles for industrial engineers in developing countries," South African Journal of Industrial Engineering, vol. 1, no. 15, pp. 43-52, 2004.

[44] P.P. Balasubramanian, “The 21st Century IE," Institute of Industrial Engineers, 2010. 